\title{
Biogas to high purity hydrogen by methane dry reforming in TZFBR+MB and exhaustion by Steam- Iron Process. Techno-economic assessment
}

by

\author{
J. Lachén, P. Durán, M. Menéndez, J.A. Peña and J. Herguido*
}

Aragon Institute of Engineering Research (I3A), Universidad Zaragoza; Mariano Esquillor, 3; Ed. "I+D”; E50.018 Zaragoza (Spain)

Telephone: +34976762393

Fax: +34 976762043

e-mail: jhergui@unizar.es

*corresponding author 


\section{Abstract}

A techno-economic study has been carried out with the aim of analyzing the performance (product distribution and energy yields) and estimating the production costs of high purity hydrogen obtained from biogas. For such purpose and taking advantage of empirical data developed in our laboratory, it has been proposed a system consisting of a two-zone fluidized bed reactor aided by a system of permselective $(\mathrm{Pd} / \mathrm{Ag})$ metallic membranes inserted in the fluidized bed (TZFBR $+\mathrm{MB})$, and a battery of several fixed bed reactors operating cycles of reduction and oxidation (Steam-Iron Process -SIP-). The feed has always been an equimolar mixture of $\mathrm{CH}_{4}$ and $\mathrm{CO}_{2}$ simulating a sweetened biogas. The first reactor $(\mathrm{TZFBR}+\mathrm{MB})$ can produce a stream of pure hydrogen (i.e. PEMFC quality) as permeated flow through the MB, and a retentate stream rich in all species resulting from the methane dry reforming reaction (MDR) and the water gas shift equilibrium (WGS). The singularity of this kind of complex reactors is that regeneration of the catalyst is performed in the same reactor and simultaneously to the MDR reaction because of the twozone. Due to the reductive behavior of the retentate stream, it can be fed to a bed of solid where up to two different oxygen carriers (iron oxide with additives and cobalt ferrite) can be reduced to their metallic state. Once the solid has been completely reduced, it can be reoxidized with steam releasing a high purity hydrogen stream. Both reactors (i.e. TZFBR + MB and SIP) have been coupled in different degrees. A performance (hydrogen and energy yields) as well as costs analysis (fixed assets and operating costs) have been performed with the aid of Aspen HYSYS v9.0, used for dimensioning the equipment needed to process up to $1350 \mathrm{~kg} / \mathrm{h}$ of biogas. On this way, the integrated process enhances the efficiencies of every single process allowing pure hydrogen yields up to $68 \%$ at $575{ }^{\circ} \mathrm{C}$ in the TZFBR+MB and an overall energy efficiency greater than $45 \%$. Production costs have been found to be in the range from 4 to $15 € / \mathrm{kg}$, still high but not so far away from the target of DOE fixed in $2 \$ / \mathrm{kg}$ by 2020 . 
Keywords: biogas, steam iron, fluidized bed, chemical looping, techno-economic assessment 


\section{INTRODUCTION}

To achieve a society based on the use of renewables, the ongoing reduction of the greenhouse emissions caused by the consumption of fossil fuels is a must. In this context, hydrogen emerges in the so called Hydrogen Economy [1] as a vector capable of fulfilling most needs. Nevertheless, since hydrogen is not found free in the atmosphere, its production implies a serious drawback: currently, most of the hydrogen production is still carried out through steam reforming of fossil fuels such as natural gas or gasification of coal [2].

Present work proposes the production of high purity hydrogen by dry reforming (MDR) of the methane contained in a biogas. This raw material, consisting basically in methane and carbon dioxide plus other impurities $\left(\mathrm{H}_{2} \mathrm{~S}, \mathrm{NH}_{3}\right.$, siloxanes...) [3], is produced by anaerobic digestion of organic matter and constitutes a clear renewable source. The original proposal consists in making use of methane dry reforming of biogas (MDR) in two non-conventional reacting systems instead of the traditional steam reforming of methane (MSR), and the subsequent hydrogen purification by pressure swing adsorption (PSA) cycles. The first system consists $(\mathrm{TZFBR}+\mathrm{MB})$ of a two-zone fluidized bed reactor (TZFBR), where due to its design, it is possible to carry out both the catalytic dry reforming reaction in one of the beds and the regeneration of the catalyst simultaneously by supplying the optimum flow of an oxidizing stream in the other [4]. The inclusion, inside the reactor bed where $\mathrm{H}_{2}$ is being produced (i.e. by MDR), of a $\mathrm{Pd} / \mathrm{Ag}$ hydrogen permselective membrane (MB), provides the traditional advantages of a membrane reactor [5,6], allowing the in-situ extraction of a high purity hydrogen permeate stream. Also, due to the features of permselective membranes, the shift of equilibrium towards products allows achieving higher methane conversions. This configuration allows intensifying the hydrogen production and its purification avoiding the use of costly PSA cycles [7]. A bimetallic Ni-Ce catalyst supported on alumina based in recent previous works [8] has been employed in this reactor.

The second system proposed for producing and purifying hydrogen consists in the steam-iron process (SIP) [9]. This is based in the redox properties of metal oxides (e.g. iron oxides). In 
brief, hydrogen is produced by reoxidation with steam of a previously reduced metal oxide, being easily separable from unreacted water by condensation. Since any stream with sufficient reductive capacity is suitable for being used in SIP [10], the possibility of using both, biogas or the exhaust gases coming from the TZFBR $+\mathrm{MB}$ reactor is proposed in the present work.

Profitability of this process is based on the capacity of the metallic oxide used as oxygen carrier, to support the largest possible number of redox cycles. This forces, on the basis of the results obtained by this research group with different raw materials [11-16], to use moderate temperatures (ca. $700{ }^{\circ} \mathrm{C}$ ) in order to avoid loss of activity due to severe sintering of the solid. On the other side, the use of low temperatures favors the production and accumulation of coke along reduction stages. That supposes an important operational problem because of an eventual reactor clogging and above all a suitable contamination of $\mathrm{H}_{2}$ by $\mathrm{CO}_{\mathrm{x}}$ in the subsequent oxidation stage. To cope with that, it has also been studied the interspersing of coke combustion stages with oxygen [17] at every given number of redox cycles, as well as co-feeding of steam along with biogas in order to prevent the eventual formation of coke [18]. In these studies, synthetic hematite and cobalt ferrites have been tested as oxygen carriers.

The aim of this work is the techno-economic analysis of combining both processes (TZBR $+\mathrm{MB}$ plus SIP) versus using both systems alone. For such purpose, a mathematical model of the whole process has been built that will serve to analyze the effect of different operating variables such as: operating temperature in TZFBR $+\mathrm{MB}$, the methodology employed to prevent the SIP reactor clogging by coke, and the grade of integration (IG), defined as the relation between the biogas flowrate fed to the joint process (TZFBR $+\mathrm{MB}$ plus SIP) versus the total biogas flowrate fed to the system (i.e. including the fraction bypassed to SIP (eq.1). (See Figure 1).

$I G=\frac{Q_{\text {biogas }}-Q_{\text {bypassedtosIP }}}{Q_{\text {biogas }}}$ 


\section{EXPERIMENTAL}

Prior to modelling the joint process (TZFBR+MB plus SIP), the experimental work has focused on the analysis of the effect of different operating variables that presumably will affect the use of synthetic mixtures $\mathrm{CH}_{4}-\mathrm{CO}_{2}$, simulating a previously desulfurized biogas. These trials have been carried out with each one of the systems (i.e. TZFBR+MB on one side, and SIP on the other) operating individually.

\subsection{Two-Zone Fluidized Bed Reactor + Membrane $(T Z F B R+M B)$}

A battery of different tests was made in a quartz reactor with an internal diameter of $2.8 \mathrm{~cm}$ and $30 \mathrm{~cm}$ of height, using a porous quartz plate to support the bed of catalyst and act as distributor plate. Methane and carbon dioxide were supplied at a middle-height point of the reactor bed using a T-shaped dip tube also made of quartz with $4 \mathrm{~mm}$ of external diameter. The regenerating agent was fed at the bottom of the fluidized bed through the quartz porous plate mentioned above. Two metallic membranes (REB Research), were immersed in the upper side of the fluidized bed with the aim of extracting hydrogen as permeate. These were $15.2 \mathrm{~cm}$ long, and had an external diameter of $3.2 \mathrm{~mm}$ and a Pd/Ag layer thickness of $76 \mu \mathrm{m}$, More details about the experimental set-up can be found in literature [19].

The catalyst used to promote the methane dry reforming reaction (MDR) was composed of 5 $\mathrm{wt} \%$ of Ni and $10 \mathrm{wt} \%$ of Ce supported on alumina (Sasol, Puralox ${ }^{\circledR}$ SCCa-150/200). It was prepared using the incipient wet impregnation method [8].

The reaction products were monitored analyzing both the permeate and the retentate stream by a gas chromatograph (Varian CP3800) equipped with MolSieve $13 X$ and HayeSep $Q$ columns. A vacuum pump was used to induce the pressure gradient needed to favor the permeation of $\mathrm{H}_{2}$ through the membranes.

All the experiments were performed between $475^{\circ} \mathrm{C}$ and $575{ }^{\circ} \mathrm{C}$, by introducing $93.75 \mathrm{~g}$ of a solid bed composed of $32 \mathrm{wt} \%$ of the earlier mentioned catalyst, and inert alumina to complete 
the balance. The particle size ranged between 106 and $180 \mu \mathrm{m}$. Alumina was incorporated for increasing the height of the bed of solid and thereby increase the extension of the reaction zone in contact with the membrane. A higher surface of membrane acting as an effective permeating layer (i.e. increased immersed membrane in the fluidized bed) allows to enhance the results obtained respecting to the former ones [8]. An equimolar mixture of $\mathrm{CH}_{4}$ and $\mathrm{CO}_{2}$ simulating a sweetened biogas constituted $60 \mathrm{v} \%$ of the total flow fed to the reactor. This mixture was fed through the T-shaped dip tube in the middle zone of the reactor. The remaining $40 \mathrm{v} \%$ consisted of the regenerating stream. It was composed of $10 \mathrm{v} \% \mathrm{O}_{2}, 5 \mathrm{v} \% \mathrm{~N}_{2}$ as internal standard and Ar to balance. The total flow supplied to the reactor was 235.5 (STP) $\mathrm{mL} / \mathrm{min}$.

\subsection{Steam-Iron Process (SIP)}

The reactor used for Steam-Iron (SIP) was a vertical quartz fixed bed reactor $\left(\varnothing_{\mathrm{i}}=13 \mathrm{~mm}\right)$ with a bed of $2.5 \mathrm{~g}$ of solid $(100<\mathrm{dp}<200 \mu \mathrm{m})$ composed of $67.5 \mathrm{wt} \%$ of oxygen carrier, $7.5 \mathrm{wt} \%$ of catalyst and $25 \mathrm{wt} \%$ of $\mathrm{SiC}$ (inert). A total flowrate of 250 (STP) $\mathrm{mL} / \mathrm{min}$ was used in all cycles (i.e. a cycle is composed of a reduction stage and an oxidation stage). Every stage was monitored by means of an Agilent $490 \mu-G C$ with columns Molisieve $5 A$ and PoraPlot $Q$, A Peltier cell acted as cool trap preventing water condensation.

Two different oxygen carriers have been tested: the first of them is a synthetic doped hematite (known as "triple oxide") composed of $98 \mathrm{wt} \% \mathrm{Fe}_{2} \mathrm{O}_{3}, 1.75 \mathrm{wt} \%$ of $\mathrm{Al}_{2} \mathrm{O}_{3}$ and $0.25 \mathrm{wt} \%$ of $\mathrm{CeO}_{2}$. It was prepared by citrates method [20]. The second reactive solid was a synthetic aluminum doped cobalt ferrite with stoichiometric formula $\mathrm{Al}_{0.53} \mathrm{Co}_{0.6} \mathrm{Fe}_{1.6} \mathrm{O}_{4}$ synthesized at lab by a fusion method [21].

In the event of interspersed coke combustions for preventing reactor clogging [17], the inlet stream in reductions was composed of $25 \mathrm{v} \%$ of an equimolar mixture $\mathrm{CH}_{4}-\mathrm{CO}_{2}, 5 \mathrm{v} \%$ of $\mathrm{N}_{2}$ as internal standard and Ar to balance. These stages were carried out at $700{ }^{\circ} \mathrm{C}$. Oxidations with steam though, were performed at $500{ }^{\circ} \mathrm{C}$ in order to avoid the gasification of the coke previously deposited in the bed. In this case, the feedstock was composed of $25 \mathrm{v} \%$ of steam, 5 
$\mathrm{v} \%$ of $\mathrm{N}_{2}$ as internal standard and Ar to complete the balance. Finally, the coke combustion stages were carried out at $600{ }^{\circ} \mathrm{C}$ feeding a gas stream with $3 \mathrm{v} \%$ of $\mathrm{O}_{2}, 5 \mathrm{v} \%$ of $\mathrm{N}_{2}$ as internal standard and Ar up to complete the balance.

When water co-feeding was used [18] for avoiding the amount of coke deposited on the solid, a stream was used with an equimolar $\mathrm{CH}_{4}-\mathrm{CO}_{2}$ mixture accounting for $25 \mathrm{v} \%$ (same as the one fed in reduction stages without steam co-feeding), steam (5 to $12.5 \mathrm{v} \%$ ) and Ar to balance. Theoretically, avoiding coke formation, it would be possible to increase the temperature of the oxidation step without the risk of gasifying the coke deposited along reduction stages. This in turn, would allow the operation at the same temperature $\left(700^{\circ} \mathrm{C}\right)$ in both stages (reductions and oxidations). No presence of $\mathrm{CO}_{\mathrm{x}}$ was detected by micro-gas chromatography ( $\left.\leq 50 \mathrm{ppm} \mathrm{CO}\right)$ in gases coming from oxidation steps. It was determined in our lab $[17,18]$ that the most adequate solid for the first mode of operation (i.e. using interspersed coke combustions) was hematite, while for co-feeding of steam, cobalt ferrite was selected as the most appropriate one.

\section{PROCESS MODELLING}

The plant model has been designed for the continuous production of hydrogen using a previously desulfurized biogas. A flowrate of $1350 \mathrm{~kg} / \mathrm{h}$ of biogas, composed of an equimolar mixture $\mathrm{CH}_{4}: \mathrm{CO}_{2}$ and supplied to the plant at 6 bar [22,23], was employed as basis of calculus. This flow of biogas represents, in volume, around half of the outlet stream produced by a wastewater treatment plant located in Baix Llobregat (Spain) [24].

Figure 2 and Figure 3 show flowsheets of the joint process, modeled with Aspen HYSYS v. $9^{\mathbb{R}}$. They present two different scenarios: when coke is burnt with oxygen in interspersed combustion stages between reduction and reoxidations with steam (Fig. 2), and those cases where steam is co-fed with the TZFBR+MB retentate stream (Fig. 3).

It can be observed in Figure 2 that supplied biogas (tagged as $\mathrm{CH}_{4}, \mathrm{CO}_{2}$-right up side of the figure-) is used to cool down the high purity hydrogen coming from the TZFBR+MB as permeated stream. Subsequently, the preheated biogas, as well as the air supplied as a 
regenerating agent, are heated up to the operating temperature of the TZFBR+MB. These streams exchange heat with those exhausts gases coming from the reduction stage of SIP (@) $\left.700{ }^{\circ} \mathrm{C}\right)$. This last stream is burned with air in excess. Flue gases are used to rise the operating temperature of the TZFBR+MB up to $700{ }^{\circ} \mathrm{C}$, as well as to satisfy the heat demands of the reduction stage, the SIP heating stages, and finally the energy demand of TZFBR+MB in case it is necessary. This reactor accommodates two simultaneous reaction: an endothermic, MDR (r.1), and an exothermic one, combustion of coke (r.2). Consequently, depending on the distribution of products, the overall process may swing from exothermic to endothermic.

$$
\begin{array}{lr}
\mathrm{CH}_{4}+\mathrm{CO}_{2} \rightarrow 2 \mathrm{H}_{2}+2 \mathrm{CO} & \left(\Delta \mathrm{Hr}_{298 \mathrm{~K}}^{o}=123.5 \frac{\mathrm{MJ}}{\mathrm{kmol}}\right) \\
\mathrm{C}+\mathrm{O}_{2} \rightarrow \mathrm{CO}_{2} & \left(\Delta \mathrm{Hr}_{298 \mathrm{~K}}^{\mathrm{o}}=-393.5 \frac{\mathrm{MJ}}{\mathrm{kmol}}\right)
\end{array}
$$

The stream that has not been permeated through the membrane in the TZFBR $+\mathrm{MB}$ is directed to the reactors in which SIP reduction stage is being carried out. It must be stressed that since this process operates in a cyclic manner, several reactors must be working in parallel, each one of them carrying out a different task (i.e. reduction, cooling, oxidation with steam, heating, burning of coke with oxygen, etc.). Figure 2 presents a single reactor while at the reduction stage (left hand side SIP block shadowed in orange). Species present in the stream exiting TZFBR, basically $\mathrm{H}_{2}, \mathrm{CO}, \mathrm{CH}_{4}, \mathrm{CO}_{2}, \mathrm{H}_{2} \mathrm{O}$ and $\mathrm{N}_{2}$, will reduce the $\mathrm{Fe}_{2} \mathrm{O}_{3}$ present in the oxygen carrier to $\mathrm{Fe}$, as well as produce the in-situ activation of the catalyst, resulting in the formation of metallic $\mathrm{Ni}$ (active species) from the $\mathrm{NiO}$ present in the bed. Distribution of gaseous products at the exit of SIP reactor, as well as the amount of deposited coke are determined by the thermodynamic equilibrium. Since reactors of the SIP process work at different temperatures depending on its duty, after reduction stage which operates typically at $700{ }^{\circ} \mathrm{C}$, it is necessary to cool down the reactor using for this purpose a closed-circuit cooling water that works between $35{ }^{\circ} \mathrm{C}$ and 45 ${ }^{\circ} \mathrm{C}$ (see the stream labelled as " $\mathrm{H}_{2} \mathrm{O}$ " which refrigerates the SIP reactor in Figure 2).

Reoxidation of the oxygen carrier with steam takes place at $500{ }^{\circ} \mathrm{C}$ releasing high purity hydrogen ("Oxidation" reactor in Figure 2). Water feedstock for oxidations (labelled as " $\mathrm{H}_{2} \mathrm{O}$ " 
in Fig. 2) is preheated by the products of the steam oxidation reactor, as well as by the heat produced along that stage (reoxidation is an exothermic reaction) and finally risen to $500{ }^{\circ} \mathrm{C}$ by interchanging heat with the exhaust gases from the reduction stage $\left(@ 700{ }^{\circ} \mathrm{C}\right)$. The products of the steam oxidation $\left(\mathrm{H}_{2}\right.$, and $\left.\mathrm{H}_{2} \mathrm{O}\right)$ are finally separated by condensation by employing the water refrigeration circuit.

Since coke does not react significantly with steam along oxidations at $500{ }^{\circ} \mathrm{C}$, after several consecutive cycles of reduction plus oxidation with steam, it is interspersed a combustion of the bed with air ("burning" reactor in the diagram of Figure 2). The purpose for that is the combustion of coke with oxygen to eliminate the carbon residue deposited along cycles. For such purpose, the reactor is heated up to $600{ }^{\circ} \mathrm{C}$ by the corresponding heating step. In this operation, also the metals present in the bed (active catalytic species) are completely reoxidized. Once combustion has removed the coke present in the reactor, it is heated again up to $700{ }^{\circ} \mathrm{C}$ and the cycle starts again.

In case of replacing the combustion stages by water co-feeding along with SIP reductive gases (see Figure 3), the process is severely simplified. The main differences rely in that a heat exchanger is added to vaporize and heat up the co-feeding water feedstock up to the temperature of the reduction stage. SIP is simplified to only two alternate stages: reduction and oxidation both carried out at $700^{\circ} \mathrm{C}$.

Both configurations use the flue gas streams for production of electricity through a Rankine cycle, employed to satisfy the energy demands of the process.

The following paragraphs describe how each of the two reactors, TZFBR+MB and SIP have been modeled individually.

\subsection{Two-Zone Fluidized Bed Reactor + Membrane $(T Z F B R+M B)$}

TZFBR + MB reactor has been modeled assuming that it will behave obtaining the same conversions and yields than those obtained in the lab-scale tests [19]. These were carried out in 
a temperature range from $475{ }^{\circ} \mathrm{C}$ to $575{ }^{\circ} \mathrm{C}$. The methane conversion $\left(\mathrm{X}_{\mathrm{CH} 4}\right)$, hydrogen yield $\left(\mathrm{Y}_{\mathrm{H} 2}\right)$ and the ratio $\mathrm{H}_{2}$ to $\mathrm{CO}\left(\mathrm{H}_{2} / \mathrm{CO}\right)$ at the exit of reactor (including both permeate and retentate streams) are shown in Figure 4. Considering these empirical results, an elemental balance was made to the entire reactor, obtaining the molar distribution of TZFBR $+\mathrm{MB}$ products. The heat demand was estimated from the global balance to the reactor, considering that it works under isothermal conditions. Finally, its sizing was carried out assuming that the space velocity in the lab-scale reactor will be to be the same to that in the industrial scale reactor, in order to keep the same fluidization behavior (same ratio of superficial gas velocity with respect to the minimum fluidization velocity). Also, the height/diameter ratio has been kept in comparison with the lab-scale reactor. Consequently, also equivalent ratios of air flowrate (as regenerating agent), catalyst load and membrane surface respecting the actual biogas flowrate have been considered.

It is expected that as result of a higher maturity of the membrane manufacturing process, it will be possible producing membranes with a lower $\mathrm{Pd} / \mathrm{Ag}$ load to reduce its cost. Keeping this in mind, in the present work it has been assumed that the membranes used on an industrial scale will present a thickness of $10 \mu \mathrm{m}$, maintaining the same perm-selectivity for hydrogen (i.e. same ratio between the flow of permeated hydrogen and the retained one as the experimentally obtained).

\subsection{Steam-Iron Process (SIP)}

As it has been verified in previous works of this research group using different biofuels [16,25], the modeling of the more complex stage of the SIP (i.e., the reduction stage) can be simplified. The simplification assumes that, due to the effect of the nickel catalyst, the decomposition of the feedstock supplied to the reduction reactor takes place instantaneously up to achieving the thermodynamic equilibrium between gaseous species. Then, the solid oxygen-carrier acts as a mere consumer of the reducing gases resulting from the feedstock decomposition. Finally, once the solid has been completely reduced, the gas equilibrium is reached again. The results 
obtained for both oxygen carriers tested (triple oxide and cobalt ferrite) [18] have been abridged by the definition of the parameters, $y_{\text {red }}, y_{\text {carrier }}$ and $y_{o x}$, as a function of the percentage of water co-fed with the biogas supplied in the reduction stage.

$y_{\text {red }}=\frac{\text { Mass of } \mathrm{H}_{2} \text { produced in oxidation stage }}{\text { Mass of }\left(\mathrm{C}+\mathrm{H}_{2}\right) \text { of } \mathrm{H}_{2}, \mathrm{CO} \text { and } \mathrm{CH}_{4} \text { present in the reduction feedstock }}$

$y_{\text {carrier }}=\frac{\text { Mass of } \mathrm{H}_{2} \text { produced in oxidation stage }}{\text { Mass of oxygen carrier present in the reactor }}$

$y_{o x}=\frac{\text { Mass of } \mathrm{H}_{2} \text { produced in oxidation stage }}{\text { Mass of steam supplied in the oxidation feedstock }}$

By means of $y_{\text {red }}$ (eq.2) it is possible to know the flow of $\mathrm{H}_{2}$ produced as a function of the gases exiting from TZFBR+MB. Knowing this one, the required mass of solid can be obtained from $y_{\text {carrier }}$ (eq.3). Finally, $y_{o x}$ (eq.4) allows the determination of the minimum flow of steam required for oxidations. Since the reactions that are taking place along the oxidation stage are (r.3) and (r.4), depending on whether the oxygen carrier employed is hematite plus additives or cobalt ferrite respectively, the amount of reacted solid as well as the amount of steam consumed can be calculated.

$3 \mathrm{Fe}+4 \mathrm{H}_{2} \mathrm{O} \leftrightarrow \mathrm{Fe}_{3} \mathrm{O}_{4}+4 \mathrm{H}_{2}$

$\mathrm{Co}+2 \mathrm{Fe}+4 \mathrm{H}_{2} \mathrm{O} \leftrightarrow \mathrm{CoFe}_{2} \mathrm{O}_{4}+4 \mathrm{H}_{2}$

Subsequently, knowing the reactions that take place along reduction stage for each one of the oxygen carriers used ((r.5) to (r.15)), it will be possible to obtain the total amount of different gaseous species consumed and produced in the redox cycle of the solid. Finally, the outlet gas composition that minimizes the Gibbs free energy (i.e. thermodynamic equilibrium) is recalculated again. By this calculation allow the estimation of the amount of coke deposited in the bed. In the case of steam co-feeding along reduction stages, the amount of steam required is 
estimated as the minimum value expected for the deposited coke to be null, according to the gas equilibrium.

$$
\begin{aligned}
& \mathrm{NiO}+\mathrm{H}_{2} \rightarrow \mathrm{Ni}+\mathrm{H}_{2} \mathrm{O} \\
& \mathrm{NiO}+\mathrm{CO} \rightarrow \mathrm{Ni}+\mathrm{CO}_{2} \\
& 4 \mathrm{NiO}+\mathrm{CH}_{4} \rightarrow 4 \mathrm{Ni}+\mathrm{CO}_{2}+2 \mathrm{H}_{2} \mathrm{O} \\
& 3 \mathrm{Fe}_{2} \mathrm{O}_{3}+\mathrm{H}_{2} \rightarrow 2 \mathrm{Fe}_{3} \mathrm{O}_{4}+\mathrm{H}_{2} \mathrm{O} \\
& 3 \mathrm{Fe}_{2} \mathrm{O}_{3}+\mathrm{CO} \rightarrow 2 \mathrm{Fe}_{3} \mathrm{O}_{4}+\mathrm{CO}_{2} \\
& \mathrm{12Fe}_{2} \mathrm{O}_{3}+\mathrm{CH}_{4} \rightarrow 8 \mathrm{Fe}_{3} \mathrm{O}_{4}+\mathrm{CO}_{2}+2 \mathrm{H}_{2} \mathrm{O} \\
& \mathrm{Fe}_{3} \mathrm{O}_{4}+4 \mathrm{H}_{2} \leftrightarrow 3 \mathrm{Fe}+4 \mathrm{H}_{2} \mathrm{O} \\
& \mathrm{Fe}_{3} \mathrm{O}_{4}+4 \mathrm{CO} \leftrightarrow 3 \mathrm{Fe}+4 \mathrm{CO}_{2}
\end{aligned}
$$

And in case of using cobalt ferrite:

$$
\begin{aligned}
& \mathrm{CoFe}_{2} \mathrm{O}_{4}+4 \mathrm{H}_{2} \leftrightarrow \mathrm{Co}+2 \mathrm{Fe}+4 \mathrm{H}_{2} \mathrm{O} \\
& \mathrm{CoFe}_{2} \mathrm{O}_{4}+4 \mathrm{CO} \leftrightarrow \mathrm{Co}+2 \mathrm{Fe}+4 \mathrm{CO}_{2} \\
& \mathrm{CoFe}_{2} \mathrm{O}_{4}+\mathrm{CH}_{4} \leftrightarrow \mathrm{Co}+2 \mathrm{Fe}+\mathrm{CO}_{2}+2 \mathrm{H}_{2} \mathrm{O}
\end{aligned}
$$

For cases where hematite plus additives was used as oxygen-carrier, a coke combustion step with air in excess was incorporated, considering that complete combustion of coke is achieved. The reactions considered are the following ((r.16) to (r.18)).

$$
\begin{aligned}
& \mathrm{Ni}+\frac{1}{2} \mathrm{O}_{2} \rightarrow \mathrm{NiO} \\
& 2 \mathrm{Fe}_{3} \mathrm{O}_{4}+\frac{1}{2} \mathrm{O}_{2} \rightarrow 3 \mathrm{Fe}_{2} \mathrm{O}_{3} \\
& \mathrm{C}+\mathrm{O}_{2} \rightarrow \mathrm{CO}_{2}
\end{aligned}
$$

Finally, once the quantities of each of the solid and gaseous species involved in each case (water co-feeding or interspersed coke combustions) are known, the corresponding global energy balances are applied to each stage in order to obtain their heat and/or cooling demands. 


\subsection{Steam-Iron Process' reactor scheduling}

Given the intrinsically non-stationary nature of the SIP process, in order to obtain a continuous production of hydrogen it will be necessary to arrange several time shifted reactors for each one of the stages (i.e. reduction, cooling, oxidation, heating and burning). A number of three reactors have been established for each stage. In case of co-feeding water along with the reductants, the residence time for each stage (reduction and oxidation) was calculated by establishing a number of 3 reactors for the stage with the shortest residence time.

In case of interspersing coke combustion stages, due to the need of performing heating and/or cooling stages, it can be up to six different stages: reduction, cooling, oxidation, heating, burning and heating. At the same time, it should be considered that the residence time of the reduction reactor must be multiple of the one for the fastest stage; otherwise there would be a waiting time that would not be possible to eliminate since the flow of reducing gases is imposed by the TZDBR $+\mathrm{MB}$, and the mass of solid is established by the $y_{\text {carrier }}$ parameter. It is hereby arbitrarily established that the heating and/or cooling steps last $10 \%$ of the duration of the reduction stage. On this way, the waiting times will come either from the oxidation stage, being able to increase the steam flow rate until eliminating standby times, or from the combustion stage, in which it will be possible increasing the air feedstock up to eliminate waiting times.

Once the number of SIP reactors has been estimated, it is possible sizing them. An acceptable pressure drop of 0.5 bar [26] has been established. With the aid of the Ergun equation, both the length of the reactors and their diameter have been calculated.

\subsection{Estimation of hydrogen cost}

Apart from the fact that an eventual combination of both reactors (TZFBR+MB and SIP) could result in an improvement or a deterioration of the $\mathrm{H}_{2}$ production, or the overall efficiency of the plant, it seems essential to analyze the cost of $\mathrm{H}_{2}$ produced in each case. This will be estimated from the simulation model, applying the percentage method already used by other authors [26], [27]. The cost of the equipment in the plant (reactors, pumps, compressors, heat exchangers, 
turbines...) was determined by correlations that depend on the design parameters of such equipment [26,28-30] (See Table 1). Applying a series of percentages [22]: it can be fixed the costs of materials, detail engineering and construction and supervision. Summing up all of them can determine the "Inside battery limits investment" (ISBL). Then, the external costs (OSBL) are estimated as a percentage of the ISBL, and finally the "Total Installation Costs" (TIC) are obtained from the sum of both. In order to get the hydrogen annual cost, it is established that the amortization is a $10 \%$ of TIC, as well as that the insurance cost are a $1 \%$ of this one. The sum of amortization costs as well as insurance costs will constitute the annual fixed costs of the plant. The variable costs are: the cost of water consumed, biogas, electricity, membranes, oxygen carriers, and catalysts. In case a surplus electricity is produced, it is considered that this will be sold at pool market price [31]. The estimation of the cost of biogas has been fixed taking into account the relation between the Low Heating Value (LHV) of the biogas and that of the natural gas, according to [31]. Biogas price include its purification costs [32]. Table 2 shows the values considered as well as the interval of costs for some variables with a certain degree of uncertainty, such as the electricity selling price, the replacement of the oxygen carriers, and the cost of spare membranes. These values have been obtained from literature [26,31-36].

\section{RESULTS AND DISCUSSION}

\subsection{Analysis of the global process efficiency}

Figure 5 shows the mass of hydrogen produced by 100 grams of $\mathrm{H}_{2}$ present (as molecular constituent of $\mathrm{CH}_{4}$ ) in biogas supplied to the process (i.e. $\mathrm{CH}_{4}: \mathrm{CO}_{2}=1: 1$ ), depending on the operating temperature in the TZFBR $+\mathrm{MB}$ for each of the cases analyzed. The yield to hydrogen using only the TZFFBR $+\mathrm{MB}$ reactor (without any SIP post-treatment) is represented by a red line. The rest of curves represent different degrees of integration of both reactors (TZFBR + MB and SIP), i.e. different values of $I G$ as defined by eq.1. For example, green lines represent the yield to hydrogen using only SIP $(I G=0)$, and black lines the yield to hydrogen when all the 
biogas supplied to the combined process is fed to the TZFBR+MB and then the outgoing retentate stream is supplied to SIP $(I G=1)$. The results plotted in continuous lines represent the operation with interspersing coke combustion stages and employing the additivated iron oxide. On the other hand, results plotted in dashed lines correspond to the operation using water cofeeding along reduction steps and using cobalt ferrite as oxygen-carrier.

Analyzing the operation with a single process, to obtain a higher production of high purity hydrogen in the TZFBR $+\mathrm{MB}$ (continuous red line) than in the SIP (green lines), it seems necessary to work at temperatures above $540{ }^{\circ} \mathrm{C}$. On the other hand, and agreeing with experimental results previously reported [17,18], it can be seen a slightly higher production of hydrogen when using additivated hematite (triple oxide) than when cobalt ferrite is used. This difference gets lower as the temperature and $I G$ values are increased. The highest performance, in terms of yield to hydrogen, is achieved when both processes are combined with a total integration $(I G=1)$, independently of the temperature at which the TZFBR+MB process works. In contrast, in the case of a partial integration of both processes $(0 \leq I G<1)$, the lower the integration degree the lower is the yield to hydrogen, measured as grams of hydrogen produced by 100 grams of molecular hydrogen present in the biogas supplied. This behavior is due to the fact that, although the composition of the stream supplied to SIP varies with the $I G$ applied, the reducing capacity of this flow is actually determined by the gas equilibrium composition at 700 ${ }^{\circ} \mathrm{C}$. Regardless of the case studied, this equilibrium implies values of reductants/oxidants concentration ratios close to 0.75 . As the efficiency of SIP is practically constant, the lower the flowrate of biogas introduced to TZFBR+MB (i.e. lower $I G$ values), the lower is the amount of $\mathrm{H}_{2}$ produced, irrespective of the temperature at which TZFBR $+\mathrm{MB}$ is operated.

Figure 6 represents the energetic yield (eq.4) obtained in each case analyzed above. These results do not make any distinction between the two modes of operation with SIP (triple oxide with interspersed combustions or cobalt ferrite with water co-feeding) since yields obtained with both of them are practically coincident. As it can be seen in Figure 6, the total integration 
of both processes $(I G=1)$ allows increasing overall efficiency of the plant up to values greater than $45 \%$.

$$
Y_{\text {energ }}(\%)=\frac{Q_{H 2} \cdot L H V_{H 2}+\text { Electricity produced }}{Q_{\text {biogas }} \cdot L H V_{\text {biogas }}+\text { Electricity consumed }}
$$

\subsection{Analysis of hydrogen production cost evolution}

Figures $7 \mathrm{a}$ and $7 \mathrm{~b}$, respectively show the cost of $\mathrm{H}_{2}$ depending on the topology of the system analyzed. These have been calculated for three different operating temperatures in the TZFBR $+\mathrm{MB}$ reactor. Costs do not differ substantially: all estimations are in the range between 4 and $15 € / \mathrm{kg}$, taking into account that the degree of uncertainty of the method of calculation employed could be as high as around 50\% [30]. The hydrogen production cost is high considering that in its estimation the impact of the subsequent stages of compression, which is necessary to supply hydrogen for fuel cell powered vehicles, has not been considered. Although some institutions have fixed the target in a selling price of $2 € / \mathrm{kg}$ by 2020 (adopted as "central target" in Figure 6) [37], at present a more realistic selling price would be rounding $9 € / \mathrm{kg}[38]$.

In terms of costs, the use of high temperatures in the TZFBR $+\mathrm{MB}$ can be justified. In almost all cases (except for the one, as it could be expected, in which only the SIP reactor is used $-I G=0$ ), the cost of hydrogen can be reduced by using the highest TZFBR operating temperature. As it can be observed, and regardless which is the oxygen carrier employed, the total integration of both processes $(I G=1)$ allows reducing the cost of the produced hydrogen. It is noticeable the fact that cost drops below $5 € / \mathrm{kg}$ employing cobalt ferrites when, on the other hand, the cost of $\mathrm{H}_{2}$ using SIP alone $(I G=0)$ has similar values irrespective of the nature of the oxygen-carrier used.

\subsection{Analysis of Steam-Iron Process}

In order to evaluate what reasons might justify a higher reduction of the $\mathrm{H}_{2}$ cost when employing cobalt ferrites; it was carried out an analysis of some of the factors affecting both, 
variable and fixed costs. Such factors are, among others, the net electricity production, the number of reactors used in SIP, and the total mass of oxygen-carrier employed. Figure 8a shows the net electricity production depending on the solid used in SIP, for all modes of operation in which SIP is carried out at some extent $(0 \leq I G \leq 1)$. For the sake of simplicity, all results shown in Figure 8 have been normalized.

Regarding the net electricity obtained, generally it is observed that the higher the temperature employed in TZFBR $+M B$, the lower is the excess electricity produced. Since all the energy demanded by the process is satisfied from burning of the exhausted stream from SIP reduction stages, the eventual excess of energy available will depend on the heating value of that stream. Thus, the higher is the temperature used in TZFBR $+\mathrm{MB}$, the greater is the amount of $\mathrm{H}_{2}$ produced, and the lower will be the heating value of the stream that feeds the combustor. This will be so regardless of the amount of reducing gases consumed in SIP process, resulting in a lower excess of produced electricity.

On the other hand, when working with partial degrees of integration $(0.25 \leq I G \leq 0.5)$, usually the lower the contribution of the TZFBR+MB (i.e. the value of $I G$ ) the higher the surplus electricity. This is due to the fact that the amount of reductive species consumed in SIP is comparable, because the presence of the catalyst makes indifferent feeding mixtures of $\mathrm{H}_{2}$ and $\mathrm{CO}$ or $\mathrm{CH}_{4}$ and $\mathrm{CO}_{2}$. The greatest differences are observed whether using triple oxide or cobalt ferrite. At $575^{\circ} \mathrm{C}$, the surplus of electricity produced by SIP using ferrite is notably greater than using triple oxide. For $I G=0$ or 1 , the process is not self-sustaining, being necessary to buy electricity from the market. This is mainly due to the fact that the requirement of incorporating coke combustion stages, as well as continuous heating and cooling stages, implies a significant waste of energy.

Regarding the number of reactors working in parallel that are required to keep the system running (see Figure 8b), it is practically negligible when using ferrites compared to the operation with interspersed combustion stages using triple oxide. This phenomenon occurs 
because of two reasons: on the one side, the lower number of stages required when water is cofed (no need of regeneration), and on the other side the complexity of sequencing each of these stages when interspersed coke combustion stages are carried out. As can be appreciated, the greater is the degree of integration of both processes $I G$, the higher is the number of reactors required. An increment in the degree of integration of both processes implies an increase of the flow of inert gas in the SIP reduction stage. The reason can be found in the dilution of air required as regenerating agent in TZFBR. The dilution causes a decrease in the residence time of reduction reactors, since the amount of solids is predetermined by the flowrate of reducing gases, $y_{\text {carrier }}$. In case that the difference between the residence time of reduction and the time spent in the remaining stages increases, a larger number of reactors will be required in the slower stages to compensate their slowness. Given the greater number of stages that implies the operation with triple oxide, this phenomenon is much more pronounced when triple oxide is employed instead of cobalt ferrite.

Finally, respecting the mass of solid employed (see Figure 8c), cobalt ferrite implies greater amounts of solid compared to triple oxide. This is mainly because of the larger amount of ferrite required for obtaining a similar hydrogen yield, since the mass of oxygen carrier contained therein is smaller compared to that of the triple oxide. Concerning the number of reactors, SIP reactors loaded with ferrites will be considerably larger than those working with triple oxide.

If the results shown in Figure 8 are contextualized with the estimated cost of $\mathrm{H}_{2}$, it can be affirmed that the lower price of $\mathrm{H}_{2}$, obtained with the total integration of both processes $(I G=1)$ when using ferrites, is due to the fact of the greater simplicity of this process. This configuration implies the use of a lower number of reactors as well as involves obtaining a greater surplus of electricity that might be sold in the market.

\section{CONCLUSIONS}

The present work analyzes the technoeconomic viability of jointly operate two processes: $i$ ) a TZFBR $+\mathrm{MB}$ reactor for production (by methane dry reforming -MDR-) and purification of 
hydrogen (by permselective separation with membranes -MB-), and ii) a SIP reactor to take advantage of the exhaust gases coming out from the TZFBR as a non-permeated stream. An integration coefficient $(I G)$ has been suggested to account for the degree of coupling between both. The operation of each reactor working alone (i.e, TZFBR+MB or SIP) has also been compared with the coupled system. A noticeable improvement in both efficiency and hydrogen production was observed when both reactors operate jointly.

The SIP operation has been analyzed by following two different strategies to cope the problem arising from coke deposition along reduction steps. The first method uses triple oxide as oxygen carrier and interspersed stages of combustion with air to remove any amount of coke present in the bed of solids. The second one uses cobalt ferrites and avoids the formation of coke along reductions by co-feeding steam together with the reductive stream. This last operation mode allows working at the same temperature in reduction and oxidation steps.

The global analysis has been modelled using Aspen HYSYS v9.0. It has been tuned up from empirical results previously obtained in lab-scale plants in our laboratories.

Regarding TZFBR $+\mathrm{MB}$, it has been observed that its operating costs are lowered as the working temperature increases. High temperatures lead to better results by producing greater flows of permeated pure hydrogen. When working at high temperature $\left(575^{\circ} \mathrm{C}\right)$ the operation with this complex kind of reactor has similar costs than operating the SIP reactor alone. For lower temperatures, the TZFBR $+\mathrm{MB}$ reactor clearly leads to the highest costs (Figure 7).

The integration of TZFBR $+\mathrm{MB}$ and SIP reactors (i.e. $I G>0$ ) seems to be interesting for both modes of operation: steam co-feeding with biogas and interspersing coke combustion stages. From the point of view of global efficiency, the coupled system enhances those found for single processes, allowing pure hydrogen yields up to $68 \%$ when working at $575{ }^{\circ} \mathrm{C}$ in the fluidized bed reactor (Figure 5). In the same vein, the integration of processes leads to improve the energy efficiency, allowing to reach an overall energy efficiency of the plant greater than $45 \%$ when working with total integration $(I G=1)$ and high temperature $\left(575{ }^{\circ} \mathrm{C}\right)$ in the TZFBR $+\mathrm{MB}$ 
(Figure 6). Regarding hydrogen production costs, SIP using triple oxides presents similar operating costs than when using cobalt ferrites. However, when TZFBR $+\mathrm{MB}$ and SIP are coupled, the greater complexity of the process and its higher energy costs (i.e. for heating and cooling) result in an unfeasible increase of hydrogen costs. In this sense, the lower cost of produced hydrogen corresponds to the fully coupled system using cobalt ferrites (i.e., water cofeeding in the SIP) and the highest temperature in the fluidized bed $\left(575^{\circ} \mathrm{C}\right)$, resulting in an estimated price of around $4.5 € / \mathrm{kg}$ (Figure 7).

All prices for $\mathrm{H}_{2}$ are estimated between 4 and $15 € / \mathrm{kg}$ which, although still far from the target of $2 \$ / \mathrm{kg}$ fixed by the American DOE by 2020 [37], as well as the $3.2 € / \mathrm{kg}$ as $\mathrm{H}_{2}$ selling price considered by Bellotti et al. [39], are in the same range. It is worth mentioning at this point that a high degree of uncertainty has been assumed due to the method used in the estimation of costs.

Just to conclude, and despite the relatively high cost obtained for hydrogen, it is worthwhile to mention that using biogas as raw material would put in value a renewable waste that does not contribute to $\mathrm{CO}_{2}$ increase in the atmosphere. 


\section{REFERENCES}

[1] Moliner R, Lázaro M, Suelves I. Analysis of the strategies for bridging the gap towards the Hydrogen Economy. Int J Hydrogen Energy 2016;41:19500-8. doi:10.1016/j.ijhydene.2016.06.202.

[2] Hosseini SE, Wahid MA. Hydrogen production from renewable and sustainable energy resources: Promising green energy carrier for clean development. Renew Sustain Energy Rev 2016;57:850-66. doi:10.1016/j.rser.2015.12.112.

[3] Tuna CE, Silveira JL, da Silva ME, Boloy RM, Braga LB, Pérez NP. Biogas steam reformer for hydrogen production: Evaluation of the reformer prototype and catalysts. Int J Hydrogen Energy 2017;43:2108-20. doi:10.1016/j.jhydene.2017.12.008.

[4] Herguido J, Menéndez M. Advances and trends in two-zone fluidized-bed reactors. Curr Opin Chem Eng 2017;17:15-21. doi:10.1016/j.coche.2017.05.002.

[5] Gallucci F, Fernandez E, Corengia P, van Sint Annaland M. Recent advances on membranes and membrane reactors for hydrogen production. Chem Eng Sci 2013;92:40-66. doi:10.1016/j.ces.2013.01.008.

[6] Fernandez E, Medrano JA, Melendez J, Parco M, Viviente JL, van Sint Annaland M, et al. Preparation and characterization of metallic supported thin $\mathrm{Pd}-\mathrm{Ag}$ membranes for hydrogen separation. Chem Eng J 2016;305:182-90. doi:10.1016/j.cej.2015.09.119.

[7] Papadias DD, Ahmed S, Kumar R, Joseck F. Hydrogen quality for fuel cell vehicles - A modeling study of the sensitivity of impurity content in hydrogen to the process variables in the SMR-PSA pathway. Int J Hydrogen Energy 2009;34:6021-35. doi:10.1016/j.ijhydene.2009.06.026.

[8] Ugarte P, Durán P, Lasobras J, Soler J, Menéndez M, Herguido J. Dry reforming of biogas in fluidized bed: Process intensification. Int J Hydrogen Energy 2017;42:1358997. doi:10.1016/j.ijhydene.2016.12.124. 
[9] Messerschmitt A. Process of producing hydrogen.- U.S. Patent No. 971,206. 971, 206, 1910.

[10] Bleeker MF, Veringa HJ, Kersten SRA. Pure Hydrogen Production from Pyrolysis Oil Using the Steam Iron Process: Effects of Temperature and Iron Oxide Conversion in the Reduction. Ind Eng Chem Res 2010;49:53-64.

[11] Campo R, Durán P, Plou J, Herguido J, Peña JA, Dur??n P, et al. Combined production and purification of hydrogen from methanol using steam iron process in fixed bed reactor. J Power Sources 2013;242:520-6. doi:10.1016/j.jpowsour.2013.05.146.

[12] Hormilleja E, Durán P, Plou J, Herguido J, Peña JA. Hydrogen from ethanol by steam iron process in fixed bed reactor. Int. J. Hydrogen Energy, vol. 39, 2014, p. 5267-73. doi:10.1016/j.ijhydene.2014.01.002.

[13] Herrer M, Plou J, Durán P, Herguido J, Peña JA, Dur??n P, et al. Hydrogen from synthetic biogas via SIP using NiAl2O4 catalyst: Reduction stage. Int J Hydrogen Energy 2014;40:5244-50. doi:10.1016/j.ijhydene.2015.01.063.

[14] Lachén J, Plou J, Durán P, Herguido J, Peña JA. Iron oxide ores as carriers for the production of high purity hydrogen from biogas by steam-iron process. Int J Hydrogen Energy 2017;42:13607-16. doi:10.1016/j.jhydene.2016.11.152.

[15] Lachén J, Durán P, Peña JA, Herguido J. High purity hydrogen from coupled dry reforming and steam iron process with cobalt ferrites as oxygen carrier: Process improvement with the addition of NiAl2O4 catalyst. Catal Today 2016;296:163-9. doi:10.1016/j.cattod.2017.04.046.

[16] Plou J, Lachén J, Durán P, Herguido J, Peña JA. Pure hydrogen from lighter fractions of bio-oil by steam-iron process: Effect of composition of bio-oil, temperature and number of cycles. Fuel 2017;203:452-9. doi:10.1016/j.fuel.2017.04.127.

[17] J. Lachén, J. Herguido JAP. High purity hydrogen from biogas via SIP: preventing 
reactor coke clogging. VI Symp. Hydrog. Fuel Cells Adv. Batter., Porto (Portugal): 2017.

[18] J. Lachén, B. López-Barranco, J. Herguido JAP. Production and purification of high purity hydrogen from biogas and water cofeeding by steam-iron process. World Hydrog. Technol. Conv., Prague (Czech Republic): 2017, p. 59.

[19] P.Durán, P.Ugarte, A. Sanz, J. Soler, M. Menéndez JH. Hydrogen production by dry reforming of biogas and separation by metallic membranes in a TZFBR reactor. VI Symp. Hydrog. Fuel Cells Adv. Batter., Porto (Portugal): 2017.

[20] Kirchnerova J, Alifanti M, Delmon B. Evidence of phase cooperation in the (Formula presented) catalytic system in relation to activity in methane combustion. Appl Catal A Gen 2002;231:65-80. doi:10.1016/S0926-860X(01)00903-6.

[21] Lázaro MJ, Echegoyen Y, Alegre C, Suelves I, Moliner R, Palacios JM. TiO2 as textural promoter on high loaded Ni catalysts for methane decomposition. Int J Hydrogen Energy 2008;33:3320-9. doi:10.1016/j.ijhydene.2008.03.050.

[22] Souza J, Schaeffern L. Sistema de Compresión de Biogas y Biometano. Inf Tecnológica 2013;24:3-4. doi:10.4067/S0718-07642013000600002.

[23] COGERSA. Captación de Biogas n.d. http://www.cogersa.es/metaspace/portal/14498/19174 (accessed November 9, 2017).

[24] Vásquez Padín JR. Planta de biogás en el sector EDAR: Análisis de problemas y soluciones. FCC Aqualia 2014:53.

[25] Plou J, Durán P, Herguido J, Peña JA. Hydrogen from bio-fuels by “steam-iron” process: Modelling and kinetics. Int J Hydrogen Energy 2016;41:19349-56. doi:10.1016/j.ijhydene.2016.05.127.

[26] Sanz A, Nieva D, Dufour J. Steam-Iron process as an alternative to Water Gas Shift 
reaction in biomass gasification. Int J Hydrogen Energy 2015;40:5074-80.

doi:10.1016/j.ijhydene.2015.02.043.

[27] Rivarolo M, Improta O, Magistri L, Panizza M, Barbucci A. Thermo-economic analysis of a hydrogen production system by sodium borohydride (NaBH4). Int J Hydrogen Energy 2018;43:1606-14. doi:10.1016/j.ijhydene.2017.11.079.

[28] Perry RH, Green DW. Perry’S Chemical Engineers' Handbook. McGraw-Hill Professional; 2008. doi:10.1036/0071511245.

[29] Towler G, Sinnott R. Chemical Engineering Desing: Principles, Practice and Economics of Plant and Process Design. 2nd Editio. Butterworth-Heinemann Press; 2013.

[30] Peters M, Timmerhaus K, Ronald W. Plant Design and Economics for Chemical Engineers. McGraw-Hill Education; 2003.

[31] MMB. El sector del biogás agroindustrial en españa. Dir Gen Recur Agrícolas Y Ganad 2010:89.

[32] Llaneza H, Morís MA, González Azpíroz L, González E. Caracterización, purificación y control de biogás. Estud Viabilidad Sist Purificación Y Aprovech Biogás 2010:1-29.

[33] IPSOM. Repaso de los precios y estado de la energía en Europa en el 2016 | Consultoría Energética Ipsom 2016. https://www.ipsom.com/2017/01/repaso-de-los-precios-yestado-de-la-energia-en-europa-en-el-2016/ (accessed November 9, 2017).

[34] Wulf J. Alibaba Group. Harvard Bus Sch 2010;9:436-52. https://www.alibaba.com/showroom/nickel-catalyst-price.html (accessed November 9, 2017).

[35] ICISpricing. Chemical market reporter 2008. www.icispricing.com (accessed November 9, 2017).

[36] Spallina V, Pandolfo D, Battistella A, Romano MC, Van Sint Annaland M, Gallucci F. 
Techno-economic assessment of membrane assisted fluidized bed reactors for pure $\mathrm{H} 2$ production with CO 2 capture. Energy Convers Manag 2016;120:257-73. doi:10.1016/j.enconman.2016.04.073.

[37] Kampman B, Leguijt C, Scholten T, Tallat-Kelpsaite J, Brückmann R, Maroulis G, et al. Optimal use of biogas from waste streams - An assessment of the potential of biogas from digestion in the EU beyond 2020. Optim Use Biogas from Waste Streams 2017:1158.

[38] Bonner B. DOE Hydrogen and Fuel Cell Technical Advisory Committee 2013.

[39] Bellotti D, Rivarolo M, Magistri L, Massardo AF. Thermo-economic comparison of hydrogen and hydro-methane produced from hydroelectric energy for land transportation. Int J Hydrogen Energy 2015;40:2433-44. doi:10.1016/j.ijhydene.2014.12.066.

\section{ACKNOWLEDGEMENTS}

Financial support for this work has been provided by the Spanish Ministerio de Economia $y$ Competitividad (MINECO), through project ENE2013-44350-R and CTQ2016-77277-R. J. Lachén also thanks the same institution for the grant BES-2014-067984. Financial aid for the maintenance of the consolidated research group CREG has been provided by the Fondo Social Europeo (FSE) through the Gobierno de Aragón (Aragón, Spain). 


\section{FIGURE CAPTIONS}

Figure 1.- Conceptual diagram of the joint process modelled

Figure 2. - Flowsheet for the configuration of TZFBR $+M B$ plus interspersed coke combustion stages in SIP

Figure 3. -Flowsheet for the configuration of TZFBR $+\mathrm{MB}$ plus water co-feeding in SIP

Figure 4.- Methane conversion $\left(\mathrm{X}_{\mathrm{CH} 4}\right), \mathrm{H}_{2}$ selectivity $\left(\mathrm{Y}_{\mathrm{H} 2}\right)$ and $\mathrm{H}_{2} / \mathrm{CO}$ molar ratio empirically obtained at different temperatures in TZFBR $+\mathrm{MB}[19]$.

Figure 5.- $\mathrm{g} \mathrm{H}_{2} / 100 \mathrm{~g}$ of biogas produced for each plant configuration. Solid lines for SIP with triple oxide. Dashed lines for SIP operated with cobalt ferrites.

Figure 6.- Energetic yield of the plant $\left(Y_{\text {energ }}\right)$ calculated for each plant configuration according to (eq.4).

Figure 7.- $\mathrm{H}_{2}$ cost obtained for each plant configuration, (a) using SIP with water co-feeding along reductions, and (b) using SIP with interspersed coke combustion stages, for three different operation temperatures at TZFBR $+\mathrm{MB}$.

Figure 8.-Normalized values of (a) net production of electricity, (b) number of SIP reactors, and (c) total load of oxygen carrier (mass), for each plant configuration adopted in the case of SIP (i.e. $I G=0$ ) as a function of the TZFBR $+\mathrm{MB}$ temperature. 
Table 1.- Expressions for equipment cost estimation.

\begin{tabular}{|c|c|c|}
\hline Equipment & Equation & Remarks \\
\hline Vessels (V) & $\left.C=13014 \cdot W \cdot \frac{L}{D}\right)^{-0.15} \cdot\left(\frac{e}{8}\right)^{-0.21}$ & $\begin{array}{l}C=\text { cost }(€)(2008) \\
L=\text { length or height }(\mathrm{m}) \\
D=\operatorname{diameter}(\mathrm{m}) \\
W=\text { weight }(t) \\
e=\operatorname{thickness}(\mathrm{mm})\end{array}$ \\
\hline Heat Exchanger (HE) & $\begin{array}{c}C=8500+1560 \cdot A^{0.75}, \quad A \leq 250 \mathrm{~m}^{2} \\
C=418 \cdot A, \quad A>250 \mathrm{~m}^{2}\end{array}$ & $\begin{array}{l}C=\text { cost }(€)(2008) \\
A=\text { exchange area }\left(\mathrm{m}^{2}\right)\end{array}$ \\
\hline Reactors & $C=$ Cost of $V+$ Cost of $H E$ & $C=\operatorname{cost}(€)(2008)$ \\
\hline Pumps & $C=6900+206 \cdot Q^{0.9}$ & $\begin{array}{l}C=\operatorname{cost}(\$)(2008) \\
Q=\text { liquid flow }(\mathrm{L} / \mathrm{s})\end{array}$ \\
\hline Compressors & $C=220000+2300 \cdot W^{0.75}$ & $\begin{array}{l}C=\operatorname{cost}(€)(2007) \\
W=\text { power }(k W)\end{array}$ \\
\hline Turbines & $C=14500 \cdot W^{0.452}$ & $\begin{array}{l}C=\operatorname{cost}(€)(2008) \\
W=\operatorname{power}(k W)\end{array}$ \\
\hline Furniture & $\begin{array}{c}C=0.18 \cdot Q, \quad Q \geq 6 \cdot 10^{6} \\
C=C \cdot 0.14 Q<6 \cdot 10^{6}\end{array}$ & $\begin{array}{l}C=\operatorname{cost}(€)(2008) \\
Q=\text { heat }(\mathrm{kcal} / \mathrm{h})\end{array}$ \\
\hline
\end{tabular}

Table 2.- Values of raw materials costs and/or reposition rates employed for cost estimation.

\begin{tabular}{|l|l|c|c|c|}
\hline Raw material & Cost & Reference & Reposition rate & Reference \\
\hline Water & $0.03 € / \mathrm{t}$ & {$[25]$} & -- & \\
\hline Electricity & $0.12 € / \mathrm{kWh}$ & {$[31]$} & -- & \\
\hline Biogas & $0.03 € / \mathrm{kg}$ & {$[29,30]$} & -- & \\
\hline Catalyst & $15 € / \mathrm{kg}$ & {$[32]$} & 0.5 (times/year) & \\
\hline Iron oxide & $2.02 € / \mathrm{kg}$ & {$[33]$} & $0-4$ (times/year) & {$[25]$} \\
\cline { 1 - 3 } Cobalt ferrite & $3.90 € / \mathrm{kg}$ & {$[33]$} & & \\
\cline { 1 - 4 } Membranes & $1500-7500 € / \mathrm{m}^{2}$ & {$[34]$} & 0.5 (times/year) & {$[34]$} \\
\cline { 1 - 4 } Electricity sale price & $0-0.086 € / \mathrm{kWh}$ & {$[29]$} & - & \\
\hline
\end{tabular}


Figure 1

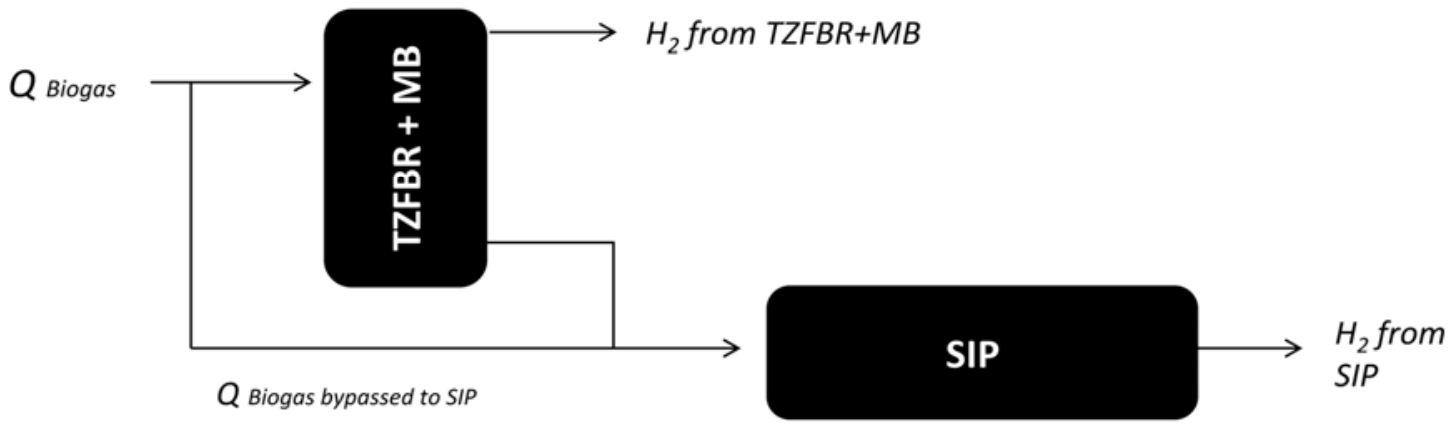

Figures_Lachen_et_al_171110

$Q$ Biogas bypassed to SIP 
Figure 2

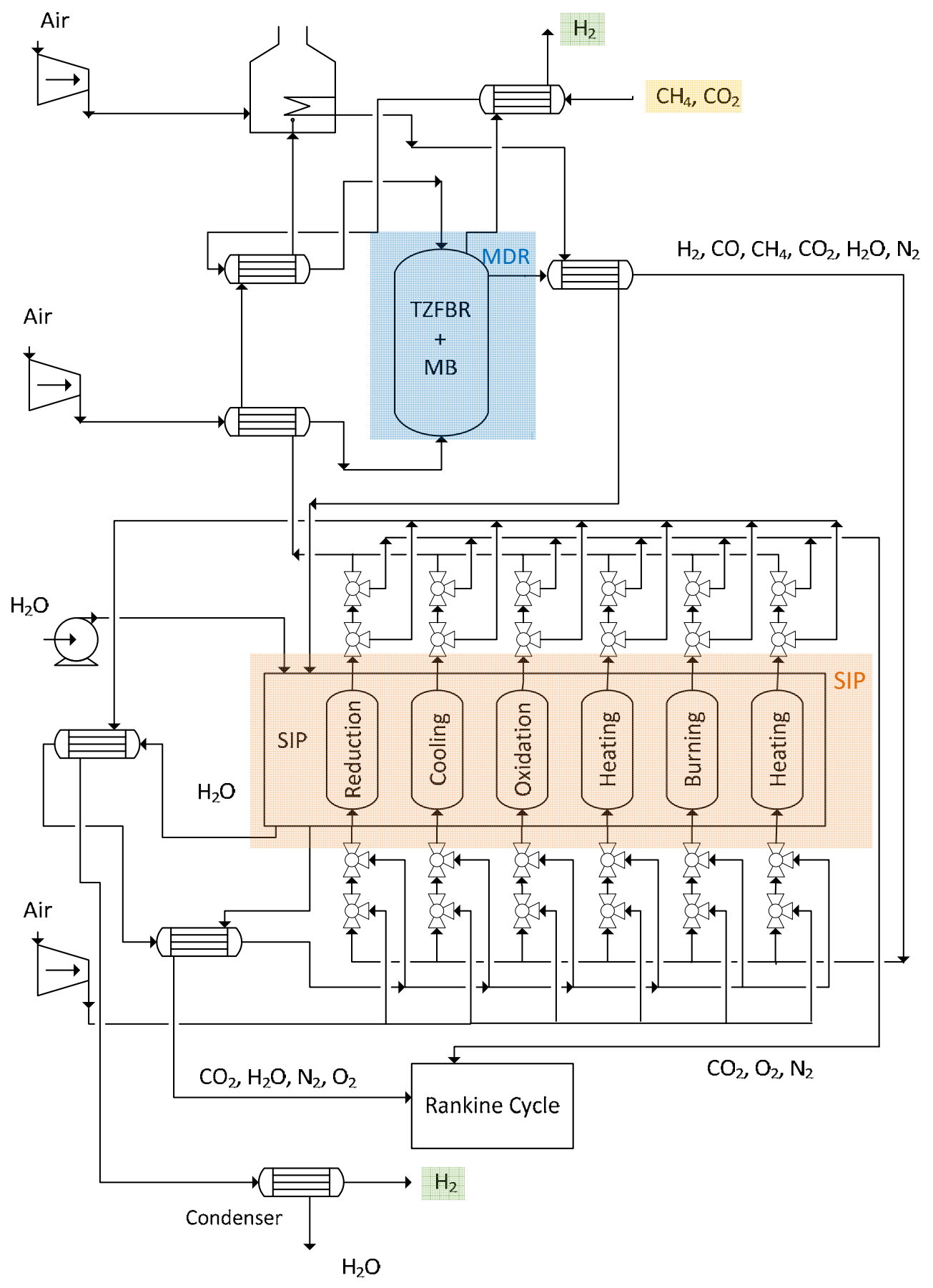


Figure 3

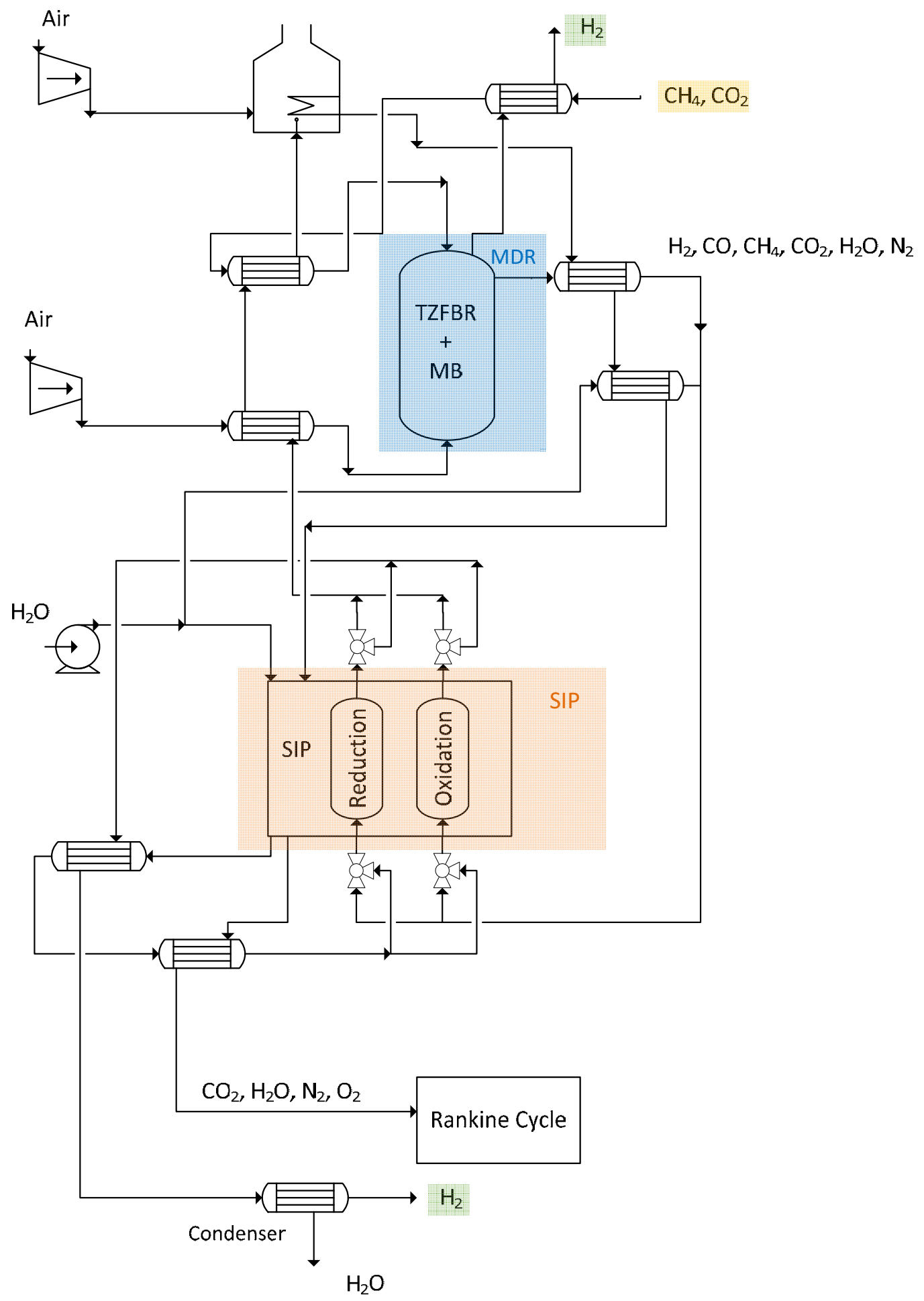


Figure 4

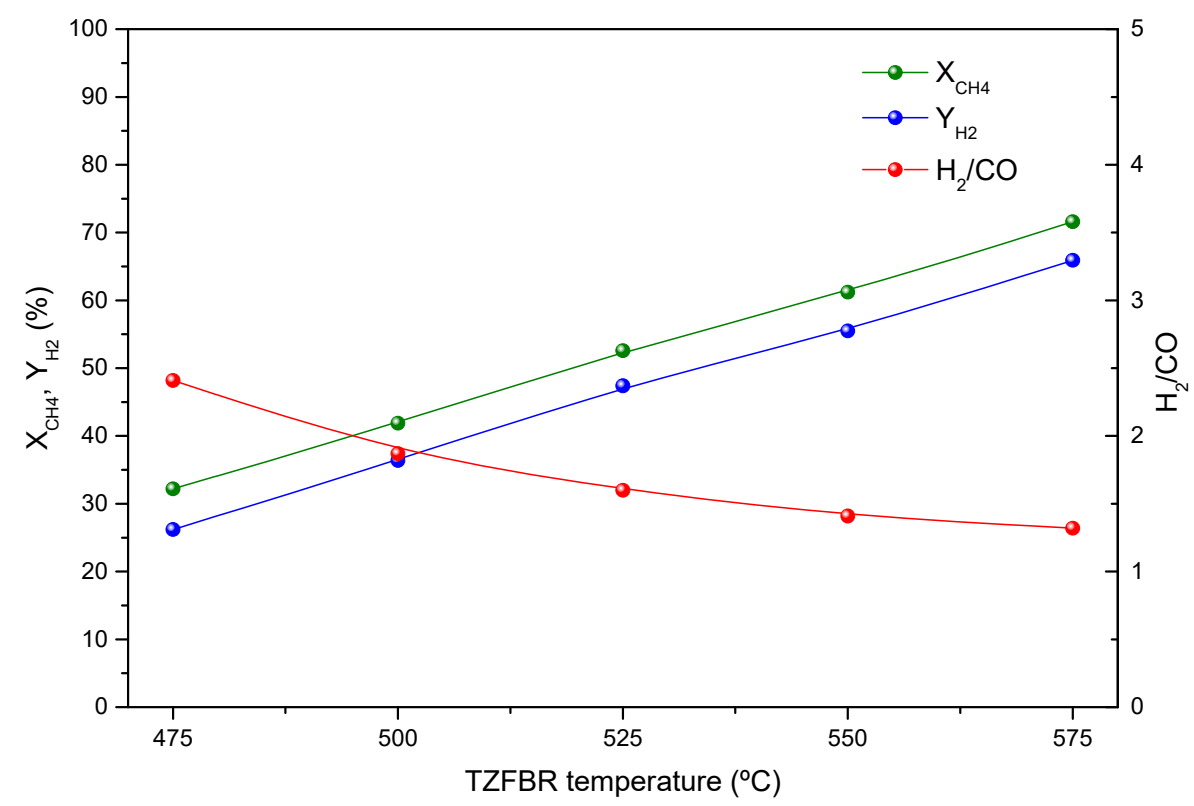


Figure 5

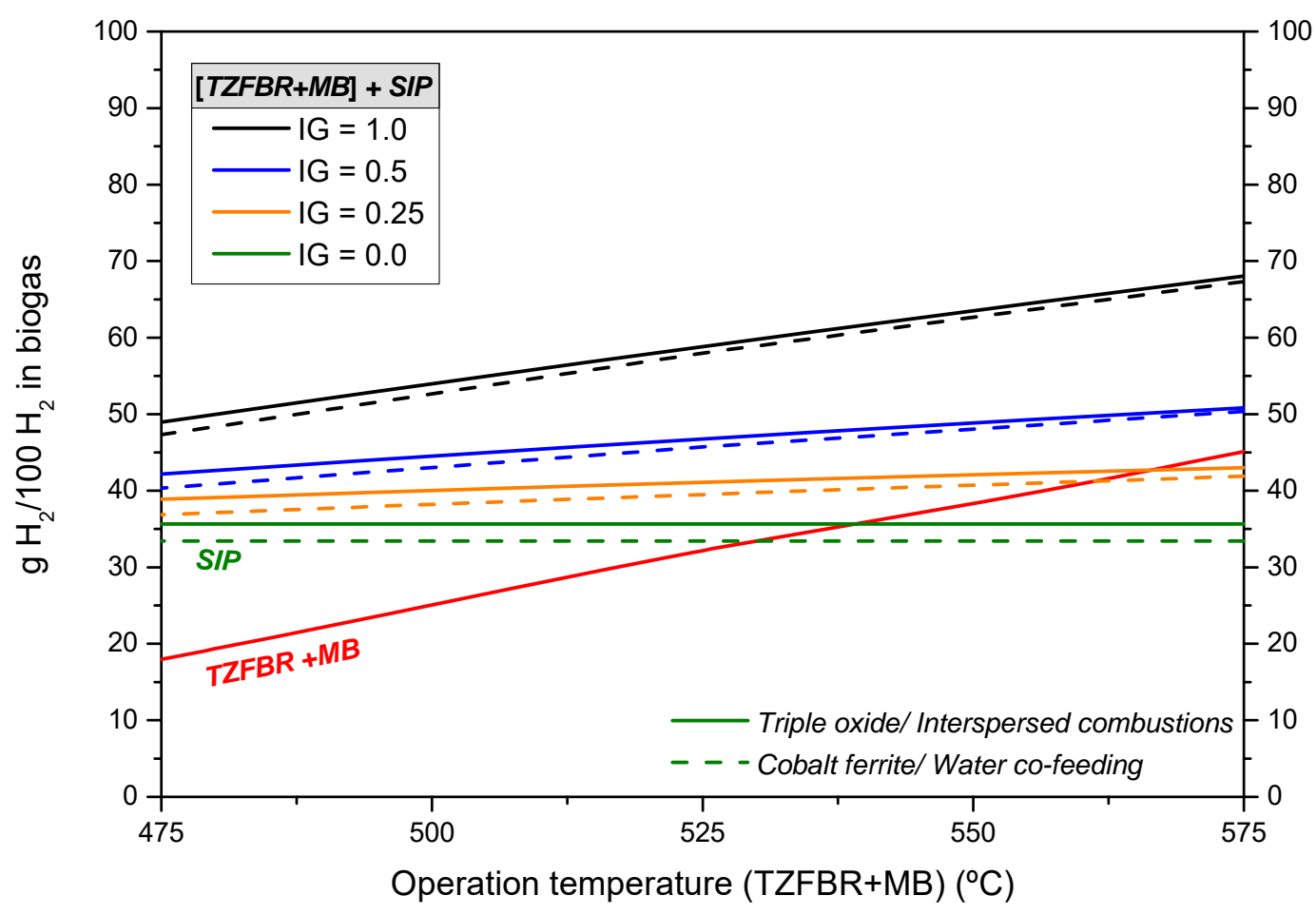


Figure 6

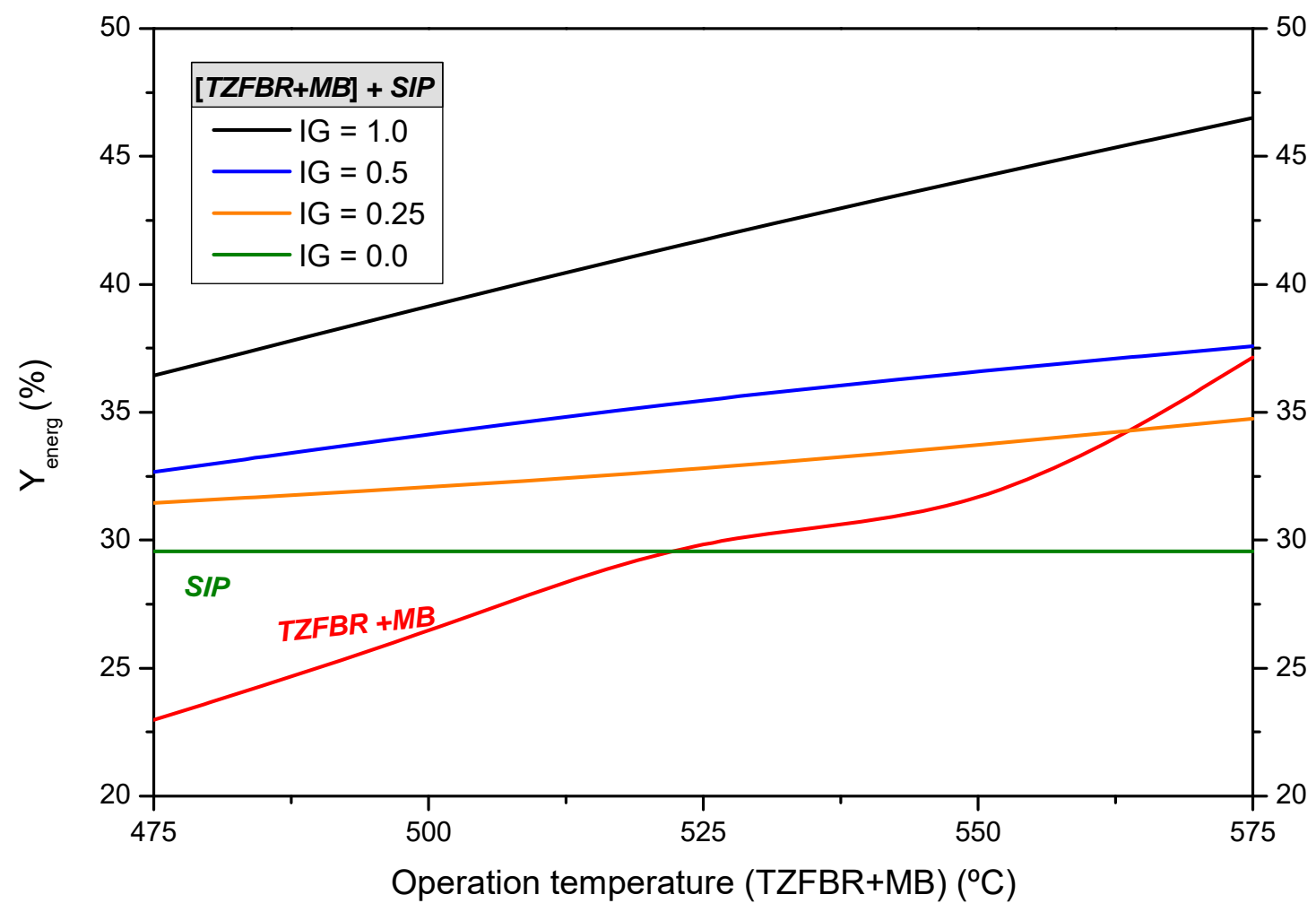


Figure 7

TZFBR operation temperature $\left({ }^{\circ} \mathrm{C}\right)$

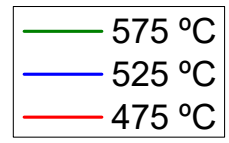

a) Ferrite/ Water co-feeding

b) Triple/ Coke burning
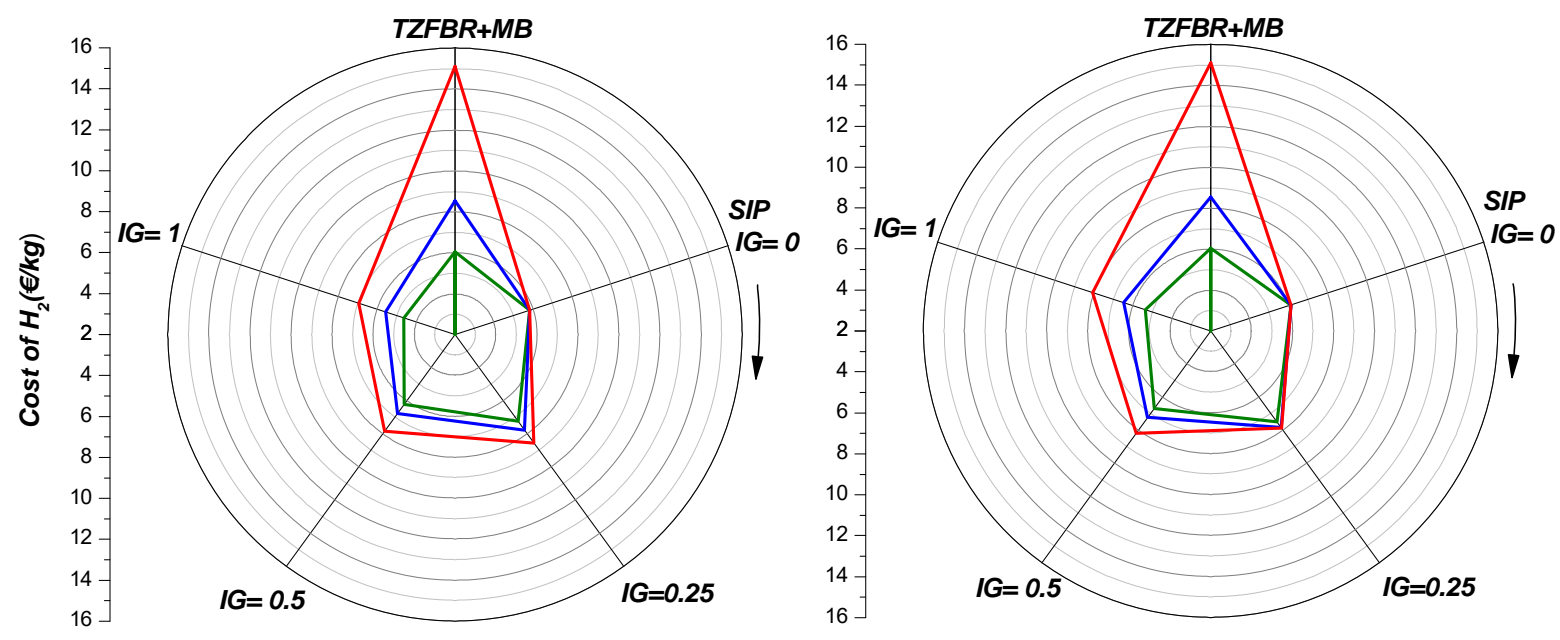
Figure 8

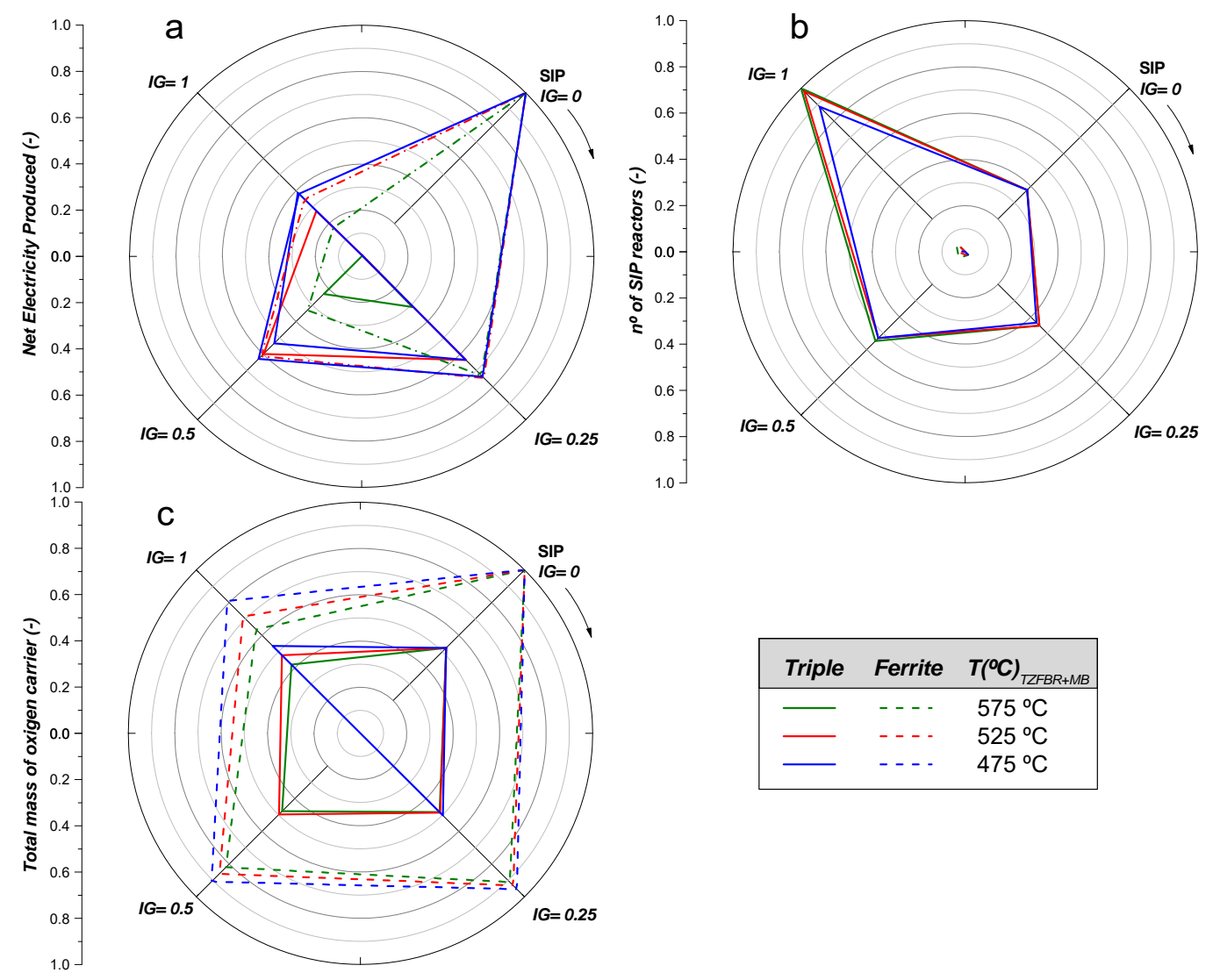

